\title{
A Remote Sensing Analysis of the Temporal and Spatial Changes of Land Surface Temperature in Calabar Metropolis, Nigeria
}

\author{
M. E. Awuh1', M. C. Officha' ${ }^{2}$, A. O. Okolie' ${ }^{3}$, I. C. Enete ${ }^{1}$ \\ ${ }^{1}$ Department of Geography \& Meteorology, NAU, Awka, Nigeria \\ ${ }^{2}$ Department of Architecture, NAU, Awka, Nigeria \\ ${ }^{3}$ Department of Architecture, Chukwuemeka Odumegwu Ojukwu University, Uli, Nigeria \\ Email: *awuhekolok@yahoo.co.uk
}

How to cite this paper: Awuh, M.E., Officha, M.C., Okolie, A.O. and Enete, I.C. (2018) A Remote Sensing Analysis of the Temporal and Spatial Changes of Land Surface Temperature in Calabar Metropolis, Nigeria. Journal of Geographic Information System, 10, 562-572.

https://doi.org/10.4236/jgis.2018.105030

Received: August 23, 2018

Accepted: October 22, 2018

Published: October 25, 2018

Copyright $(9) 2018$ by authors and Scientific Research Publishing Inc. This work is licensed under the Creative Commons Attribution International License (CC BY 4.0).

http://creativecommons.org/licenses/by/4.0/

\begin{abstract}
This study investigated the temporal and spatial changes of land surface temperature (LST) over Calabar Metropolis, Nigeria (2002 to 2016). The LST over Calabar metropolis was studied from the analysis of Landsat imageries of the investigated years $(2002,2006,2008,2010,2012,2014$ and 2016). The results of the LST imagery were classified using standard deviation. GIS was further applied to extract the coverage ratio of each land use in the context of Land surface temperature (LST) pixels and results were presented in degree Celsius. The result of this study revealed a great variation in the mean LST for the selected period. The highest mean LST of $25.38^{\circ} \mathrm{C}$ was observed in 2016 , followed by 2002 with mean LST of $25.32^{\circ} \mathrm{C}$ whereas, the least LST was observed in 2010. This study has shown that, the changing land use pattern of the area is capable of affecting certain characteristics of the environment such as surface temperature. The study recommends that effort should be made by the government to increase urban vegetation in order to reduce potential future increased in LST.
\end{abstract}

\section{Keywords}

Landsat Imageries, Calabar, Land Surface Temperature, Spatial Changes

\section{Introduction}

Land surface temperature (LST) which is controlled by the surface energy balance, atmospheric state and thermal properties of the surface/subsurface rocks is one of the important parameters in several environmental models [1]. As suggested by [2], LST provides an accurate measure for indicating energy exchange 
balance between the Earth and the atmosphere. Studies on LST are important to environmental studies and management of the Earth's resources due to its ability to determine the effective radiating temperature of the Earth's surface. Also, LST is a major factor of determining the partition of the available energy into sensible and latent heat flux. For example, the rate of change of LST is sensitive to the characteristics of the land surface such as soil moisture, land use and vegetation [3].

With the advent of thermal remote sensing technology, observation of LST has become possible using Satellite and Aircraft platforms [4], which has provided the new direction for the observations of thermal reflectance and the study of their effects through the combination of thermal remote sensing and urban micrometeorology [5]. Various satellites, and methods such as Landsat TM Bands are available that can be used to examine the LST [6] [7] [8] [9]. Landsat TM Bands are the data which is most widely used for these studies [6] [7] [8] [9]. Previous studies have demonstrated that the LST product retrieved from thermal infrared (TIR) sensors can be used to monitor the distribution of temperature over an area [5] [10] [11] [12] [13] [14]. Several researchers have estimated air temperatures using Landsat TM Imageries [7] [15]-[20]. This paper assesses the temporal and spatial changes of LST over Calabar Metropolis, Nigeria.

\section{Materials and Method}

\subsection{Study Area}

Calabar Metropolis, the study area, is the capital of Cross River State, Nigeria, located at the Southern part of the State. It encompasses of Calabar Municipality and Calabar South Local Government Areas and lies between latitudes $4^{\circ} 50^{\prime} \mathrm{N}$ and $5^{\circ} 10^{\prime} \mathrm{N}$ and longitudes $8^{\circ} 17^{\prime} \mathrm{E}$ and $8^{\circ} 20^{\prime} \mathrm{E}$; bounded to the north by Odukpani Local Government Area (LGA) and to the East by Akpabuyo LGA. Calabar Metropolis is sandwiched between the Great Kwa River to the East and the Calabar River to the West. The present of urban area is on the eastern bank of the Calabar River, its growth of the southern part is hindered by the mangrove swamps. It covers an estimated land area of about $274.593 \mathrm{~km}^{2}$ (Figure 1).

Calabar falls within tropical equatorial (Af) climate of high temperature, high relative humidity and abundant annual rainfall [21]. The annual rainfall is 2750 $\mathrm{mm}$ and the mean annual average temperature is $26.1^{\circ} \mathrm{C}$. The study area has witnessed a tremendous increase in the population of 10,000 estimated at the pre-colonial, to 99,352 in 1993; 328,876, in 1991. The last census in 2006 put the population to 371,022 [22]. The population growth of Calabar has been followed by the expansion of its physical boundaries. This increase in the physical boundaries implies a corresponding loss of vegetation and land in the area thereby a direct impact on the micro-climate [22].

\subsection{Image and Pre-Processing}

Landsat cloud-free imageries were acquired from the NASA web site which 


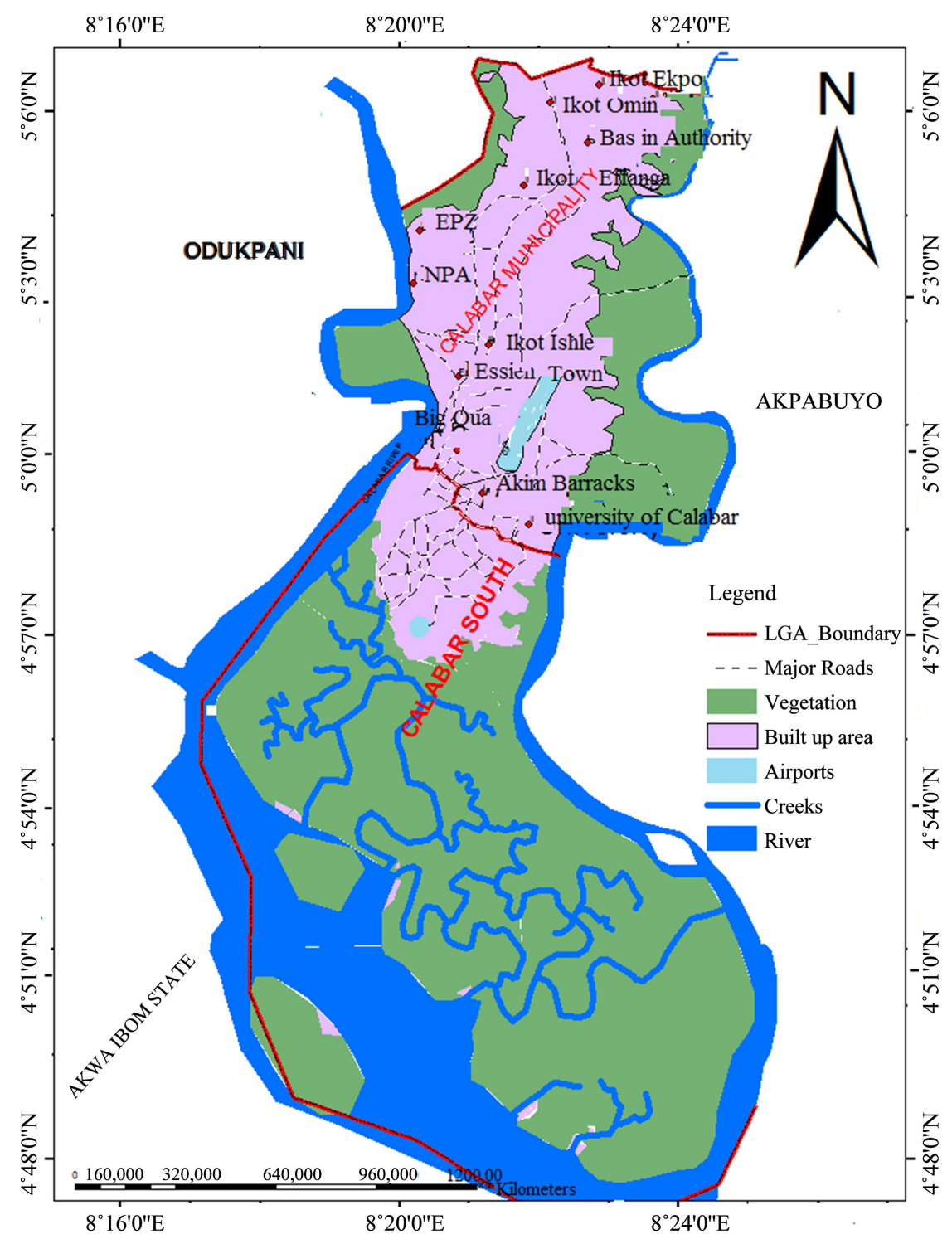

Figure 1. Map of the study area.

comprised of the Thematic Mapper (TM), Enhance Thematic Mapper plus $\left(\mathrm{ETM}^{+}\right)$image and the operational land Imager (OLI) to determine LST within Calabar Metropolis between "2002 and 2016". The imageries downloaded covered a period of 15 years at an interval of 2 years. The software employed for desktop analysis was ArcGIS. Identifying the study area was the first step of this research which was achieved with the use of an administrative map of Calabar, showing Calabar Municipality and Calabar South LGA.

\subsection{Retrieving of Land Surface Temperature}

Land surface temperature was estimated using various procedures which range from radiometric calibration, conversion of $\mathrm{DN}$ to radiance, correction for atmospheric absorption, re-emission and surface emissivity which has been used in [23] as described below: 


\section{Conversion of Digital Numbers (DN) of the bands to Spectral Radiance}

$$
L_{\lambda}=\left\lfloor\frac{L_{\mathrm{MAX}}-L_{\mathrm{MIN}}}{Q_{\text {Calma }} x-Q_{\text {CALMIN }}}\right\rfloor \times(D N-1)+L_{\mathrm{MIN}}
$$

where,

$L_{\mathrm{MAX}}=$ the spectral radiance that is scaled to $Q_{\text {CALMAX }}$ in $\mathrm{W} /\left(\mathrm{m}^{2}{ }^{*} \mathrm{sr}^{*} \mu \mathrm{m}\right) L_{\mathrm{MIN}}$ $=$ the spectral radiance that is scaled to $Q_{\text {CALMIN }}$ in $\mathrm{W} /\left(\mathrm{m}^{2}{ }^{*} \mathrm{sr}^{*} \mu \mathrm{m}\right) Q_{\text {CALMAX }}=$ the maximum quantized calibrated pixel value (corresponding to $L_{\mathrm{MAX}}$ ) in $D N=$ $255 Q_{C A L M I N}=$ the minimum quantized calibrated pixel value (corresponding to $\left.L_{\mathrm{MIN}}\right)$ in $D N=1$.

Conversion from Spectral Radiance to At-Satellite Brightness Temperature [23]

$$
T=\frac{K_{2}}{\operatorname{In}\left(\frac{K_{1}}{L_{\lambda}}+1\right)}-273.15
$$

where, $T=$ At-satellite brightness temperature, $L_{1}=$ Spectral radiance (gotten from equations - and -), $K_{1}=$ Band specific thermal conversion constant from the metadata, $\mathrm{x}$ is the thermal band number), $K_{2}=$ Band specific thermal conversion constant from the metadata, $-273.15=$ Constant for conversion from Kelvin to Degrees Celsius as shown in [23].

Correcting for Land Surface Emissivity (LSE) [23]

The temperature values obtained using Equation (2) are reference to a blackbody. Therefore, corrections for spectral emissivity $(\varepsilon)$ became necessary according to the nature of land cover (Equation (3))

$$
e=0.004 P_{V}+0.986
$$

where, $e=$ Land Surface Emissivity, $0.004 \& 0.986=$ Constants for emissivity estimation, $P_{V}=$ Proportion of vegetation [23] given by the equation

$$
P_{V}\left(\frac{N D V I-N D V I_{\min }}{N D V I_{\max }-N D V I_{\min }}\right)
$$

where, $N D V I=$ Normalized Differential Vegetation Index as computed with Equation (1) for each of the years, $N D V I_{\min }=$ Minimum value of $N D V I$ for that year, $N D V I_{\max }=$ Maximum value of $N D V I$ for that year [23].

Estimation of the Land Surface Temperature [23]

$$
L S T=\frac{B_{T}}{1+W} \times \frac{B_{T}}{P} \times \operatorname{In}(\Sigma)
$$

where, $L S T=$ Land Surface Temperature, $B_{T}=$ At-satellite brightness temperature, $\mathrm{W}=$ Wavelength of emitted radiance $(\mu \mathrm{m})[23]$ given as:

$$
P=h \times \frac{c}{s}\left(1.438 \times 10^{-2} \mathrm{mK}\right)=14380
$$

$h=$ Planck's constant $\left(6.626 \times 10^{-34} \mathrm{Js}\right), S=$ Boltzmann constant $\left(1.38 \times 10^{-23} \mathrm{~J} / \mathrm{K}\right)$, $C=$ Velocity of light $\left(2.998 \times 10^{8} \mathrm{~m} / \mathrm{s}\right), e=$ LSE. 


\section{Result Presentation and Discussion}

\section{Land Surface Temperature (LST) Analysis}

Based on the LST retrieval algorithm mentioned earlier, seven LST maps at an interval of two years (2002 to 2016) were generated to measure the magnitude and to quantify LST spatially explicit over the whole study area. In order to display the LST map clearly, the density slice function of ArcGIS was used to distinguish the LST zones by different colors. The LST over Calabar metropolis was studied from the analysis of Landsat images of the investigated years (2002, 2006, 2008, 2010, 2012, 2014 and 2016). The results of the LST imagery were classified using standard deviation. LST for the different years was also extracted and presented in degree Celsius (Figure 2 and Table 1).

The result of the LST maps revealed a great variation in the surface radiant temperature for the selected periods (Figure 2 and Table 1). Comparing radiant temperature for the selected periods we observed that, in 2002, the radiant temperature is confined within the range of $14.19^{\circ} \mathrm{C}$ to $31.4^{\circ} \mathrm{C}$ with mean of 25.32 ${ }^{\circ} \mathrm{C}$; while the radiant temperature of 2006 falls within the range of $18.77^{\circ} \mathrm{C}$ to $30.52^{\circ} \mathrm{C}$ with a mean of $23.76^{\circ} \mathrm{C}$. Also, in 2008 , the radiant temperature falls within the range of $18.92^{\circ} \mathrm{C}$ to $32.14^{\circ} \mathrm{C}$ with a mean of $24.63^{\circ} \mathrm{C}$ while the radiant temperature of 2010 falls within the range of $14.18^{\circ} \mathrm{C}$ to $24.77^{\circ} \mathrm{C}$, with $18.72^{\circ} \mathrm{C}$ as the mean. The result also revealed a great variation in the mean LST for 2008, 2006 and 2002. Comparing mean LST of 2008 with 2002 and 2006, we observed a slight negative difference of $-0.69^{\circ} \mathrm{C}$ and a positive difference of $1.26^{\circ} \mathrm{C}$ in 2002 and 2006 respectively (Table 1).

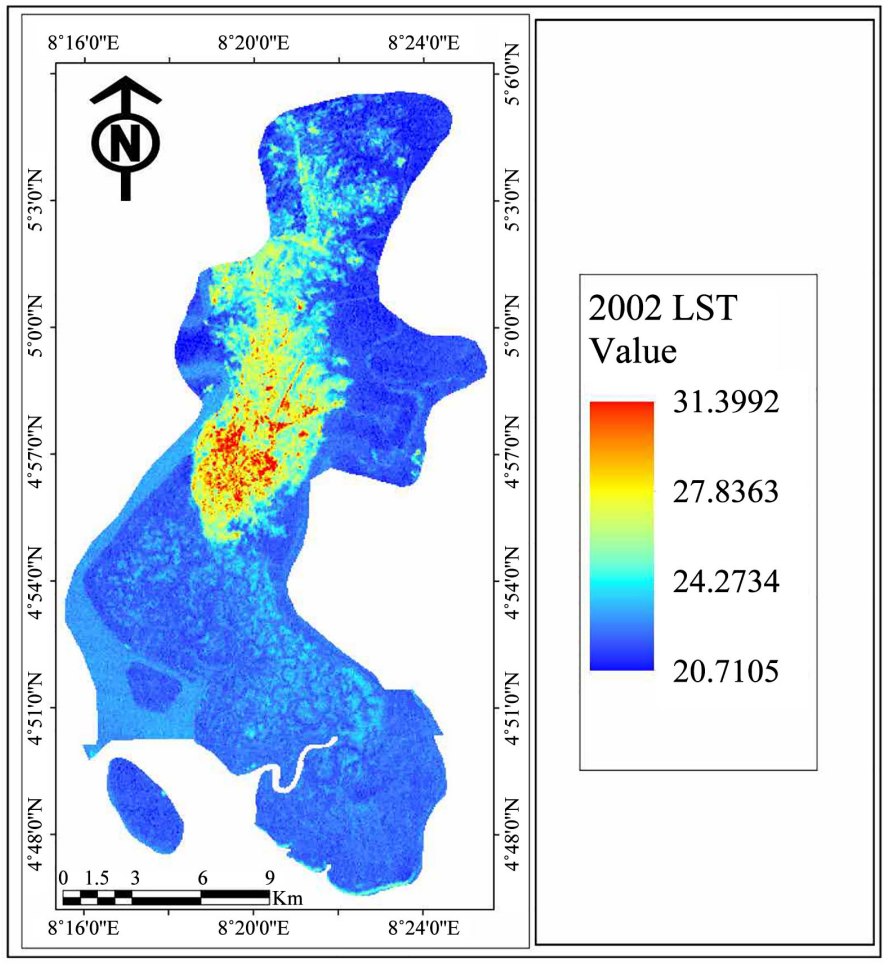

(a) 


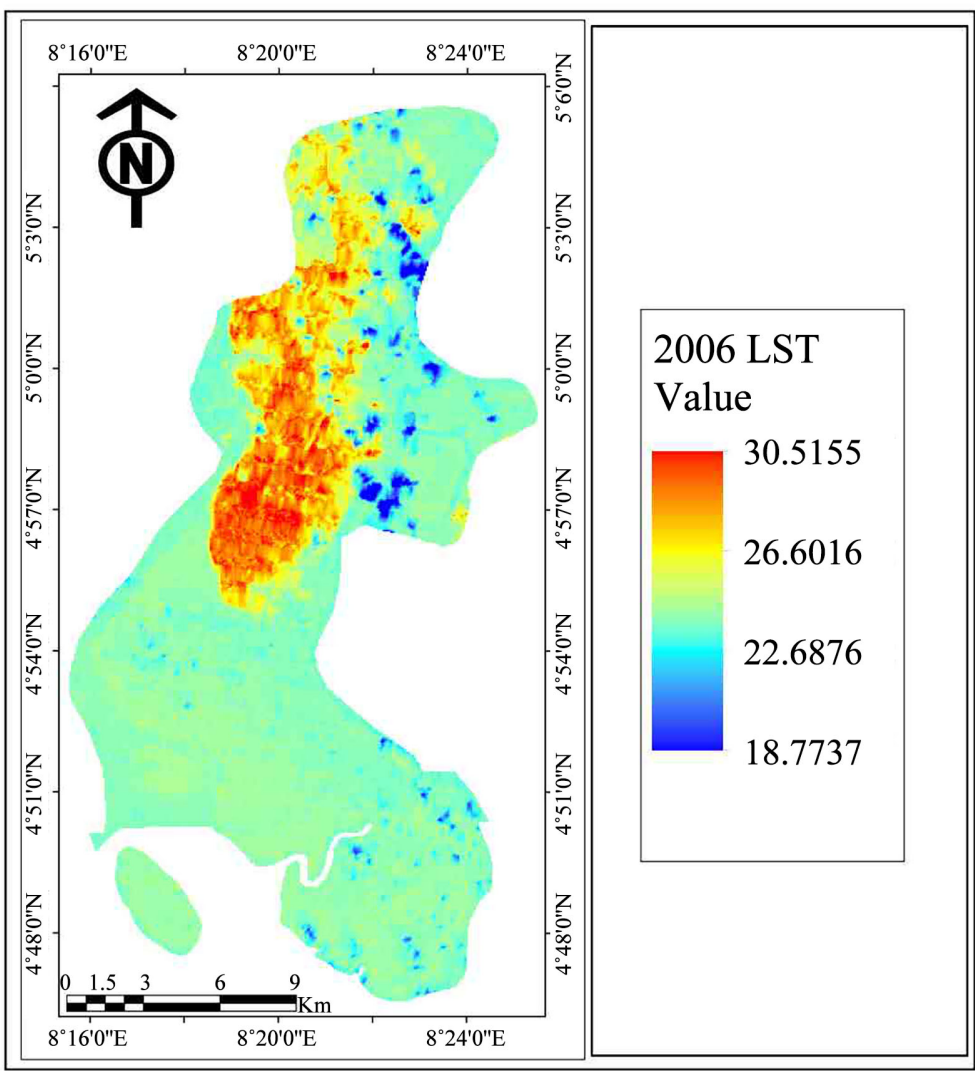

(b)

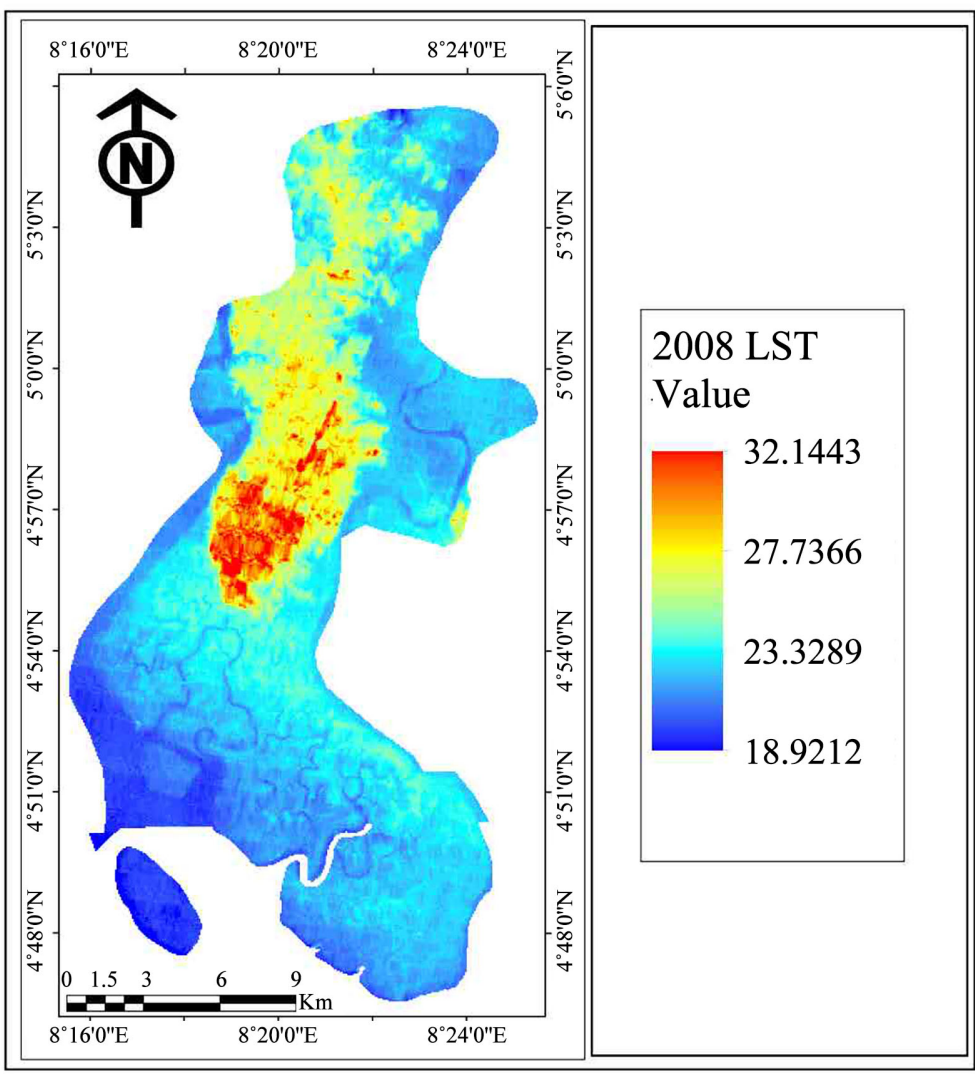

(c) 


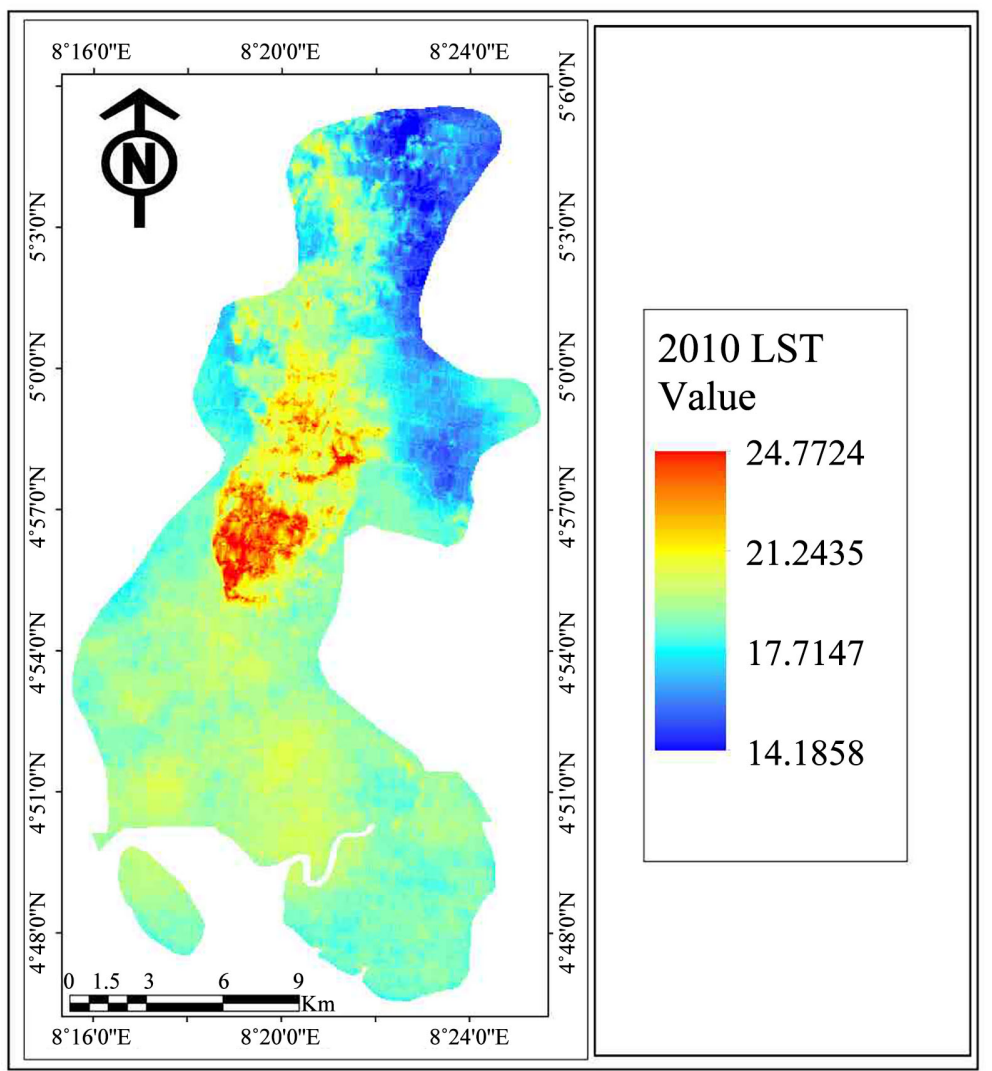

(d)

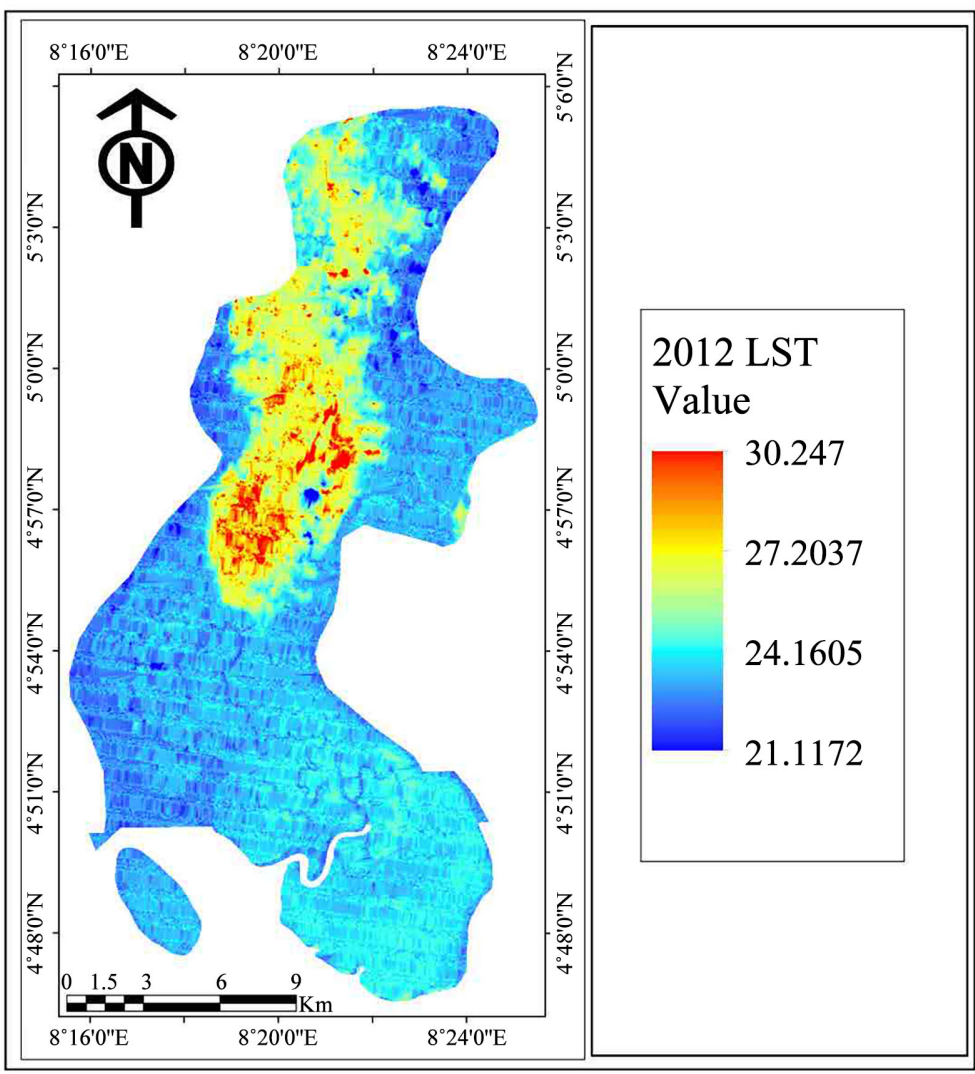

(e) 


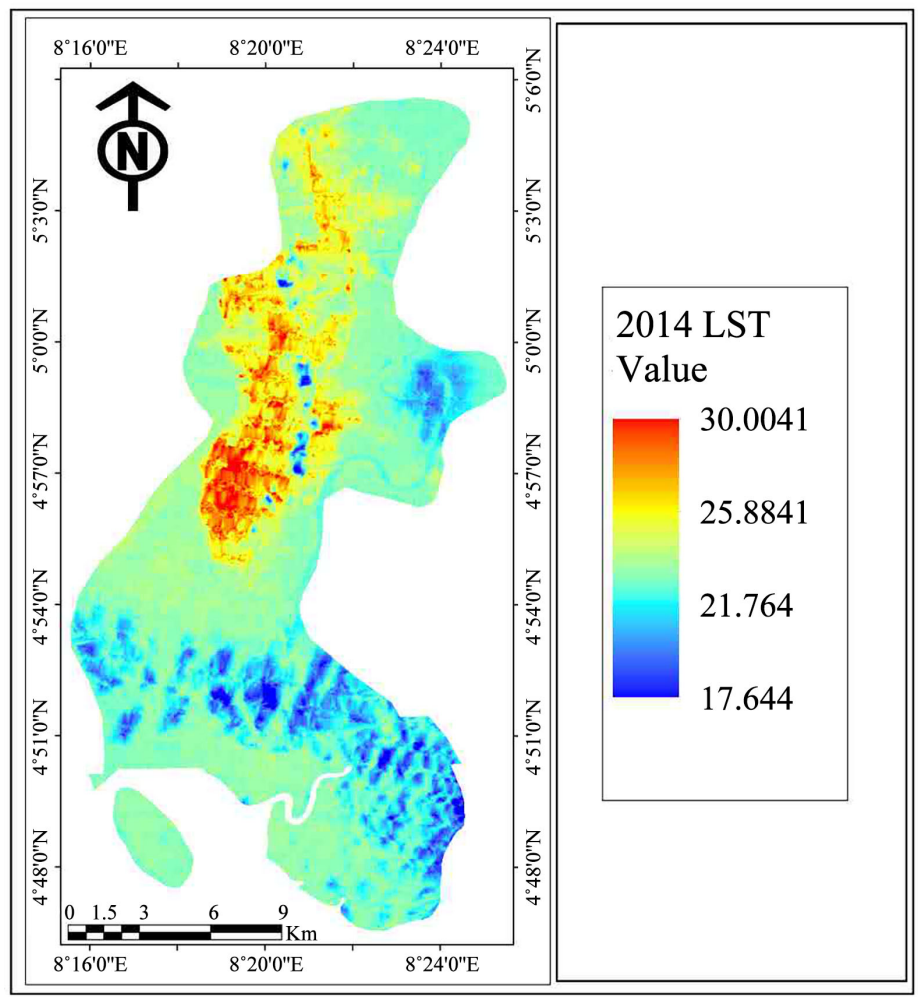

(f)

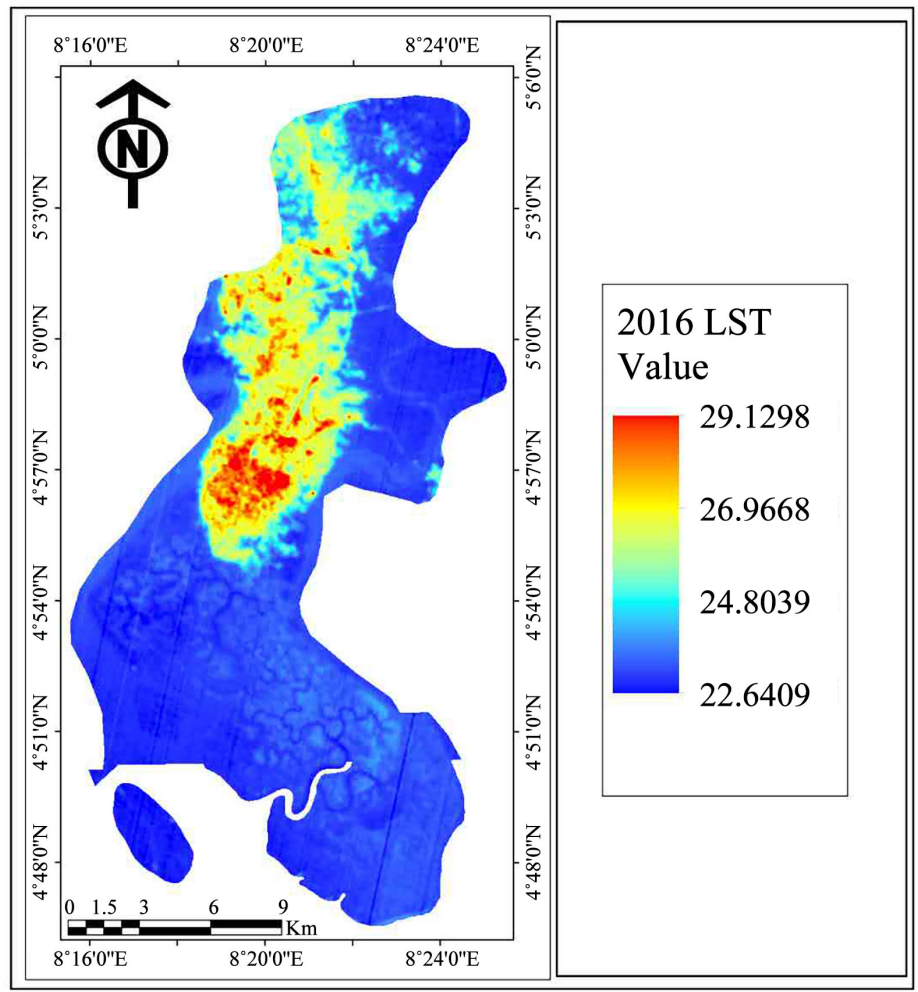

(g)

Figure 2. LST distribution over Calabar Metropolis based on Landsat 7 imageries in 2002 (a), 2006 (b), 2008 (c), 2010 (d), 2012 (e), 2014 (f) and 2016 based on Landsat 8 Image (g). 
Table 1. LST change status of Calabar Metropolis (2002-2016).

\begin{tabular}{cccccccc}
\hline & 2002 & 2006 & 2008 & 2010 & 2012 & 2014 & 2016 \\
\hline Class_name & LST $\left({ }^{\circ} \mathrm{C}\right)$ & LST $\left({ }^{\circ} \mathrm{C}\right)$ & LST $\left({ }^{\circ} \mathrm{C}\right)$ & LST $\left({ }^{\circ} \mathrm{C}\right)$ & LST $\left({ }^{\circ} \mathrm{C}\right)$ & LST $\left({ }^{\circ} \mathrm{C}\right)$ & LST $\left({ }^{\circ} \mathrm{C}\right)$ \\
Waterbody & 20.71 & 18.74 & 18.92 & 14.19 & 21.12 & 17.64 & 22.26 \\
$\begin{array}{c}\text { Sparse } \\
\text { Vegetation }\end{array}$ & 24.27 & 22.68 & 23.23 & 17.71 & 24.16 & 21.76 & 24.80 \\
$\begin{array}{c}\text { Dense } \\
\text { Vegetation }\end{array}$ & 22.40 & 20.63 & 21.13 & 15.70 & 22.64 & 19.70 & 23.72 \\
$\begin{array}{c}\text { Built-Up } \\
\text { Barelands }\end{array}$ & 27.40 & 30.13 & 32.14 & 24.77 & 30.25 & 30.00 & 29.13 \\
Mean & 25.32 & 23.76 & 24.63 & 18.72 & 25.07 & 23 & 25.38 \\
\hline
\end{tabular}

Furthermore, the result of the LST map of 2012 reveals the highest mean radiant temperature in 2012 to be $30.25^{\circ} \mathrm{C}$, followed by $21.12^{\circ} \mathrm{C}$ with a mean of $25.07^{\circ} \mathrm{C}$, higher than that of 2010 . In 2014 , radiant temperature falls within the range of $17.64^{\circ} \mathrm{C}$ to $30.00^{\circ} \mathrm{C}$ with a mean of $23^{\circ} \mathrm{C}$ (Table 1 ). The result of the 2014 LST map further revealed the mean LST of 2014 to be higher than the mean LST of 2010, but lower than the other years understudy. Comparing mean LST of 2014 and 2012, we observed that mean LST in 2012 was higher than 2014 (Table 1).

From the findings of this study, it is evident that, the highest mean radiant of $25.38^{\circ} \mathrm{C}$ was observed in 2016 , followed by 2002 with mean LST of $25.32^{\circ} \mathrm{C}$, while the least radiant temperature was observed in 2010 (Table 1). The low mean value of the radiant temperature in 2010 compared to the other years can be attributed to the adverse weather condition such as dust haze and fog reported by [24], during the months of January to March, November to December 2010, dry north easterly winds prevailed over parts of West Africa as a result of surface pressure built up over the Sahara deserts and Sahel region which transported air borne dust particles southward, thus, reducing the horizontal visibility to less than $1000 \mathrm{~m}$.

The findings of this study also demonstrated that, out of the five land use classes identified in the study area (water body, sparse vegetation, dense vegetation, built up area and bare land) [25], built-up and bare land LULC classes exhibited the highest mean LST values. The mean LST value of $32.14^{\circ} \mathrm{C}$ was observed around the bareland class while the lowest radiant temperature of $14.19^{\circ} \mathrm{C}$ was observed around the water body classes (Table 1 ).

\section{Conclusion}

This study has demonstrated that, Land Surface Temperature (LST) values have grown from the 2002 extent to the 2016 size and their spatial extent is getting larger as urbanization intensifies. The result revealed that the built-up area was the land use category that was significantly linked to high mean and high LST. The study also revealed that the lowest mean LST corresponded to areas covered 
by water bodies, followed by areas over woodland. The removal of the vegetal cover exposes the land surface to insolation expressed in reflectance that signifies the heating or cool surface systems. The sequence indicates that abundant water is helpful in buffering urban heat islands (UHIS). Vegetation covers should be protected to reduce potential future UHIS around the urban fringe transits through a peri-urban heating system.

\section{Conflicts of Interest}

The authors declare no conflicts of interest regarding the publication of this paper.

\section{References}

[1] Becker, F. and Li, Z. (1990) Towards a Local Split Window Method over Land Surface. International Journal of Remote Sensing, 3, 17-33.

[2] Liu, L. and Zhang, Y. (2011) Urban Heat Island Analysis Using the Landsat TM Data and ASTER Data. A Case Study in Hong Kong. Remote Sensing, 3, 1535-1552. https://doi.org/10.3390/rs3071535

[3] Fabrizi, R., Bonafoni, S. and Biondi, R. (2010) Satellite and Ground-Based Sensors for the Urban Heat Island Analysis in the City of Rome. Remote Sensing, 2, 1400-1414. https://doi.org/10.3390/rs2051400

[4] Ema, K., Nengah, I.S. and Widiatmaka, J. (2016) Satellite-Based Land Surface Temperature Estimation of Bogor Municipality, Indonesia. Indonesian Journal of Electrical Engineering and Computer Science, 2, 221-228. https://doi.org/10.11591/ijeecs.v2.i1.pp221-228

[5] Vought, J.A. and Oke, T.R. (2003) Thermal Remote Sensing of Urban Areas. Remote Sensing of Environmental, 86, 370-3884. https://doi.org/10.1016/S0034-4257(03)00079-8

[6] Sekertekin, A., Kutoglu, S.H. and Kaya, S. (2016) Evaluation of Spatiotemporal Variability in Land Surface Temperature: A Case Study of Zonguldak, Turkey. Environmental Monitoring and Assessment, 188, 1-15. https://doi.org/10.1007/s10661-015-5032-2

[7] Wang, F., Qin, Z.H., Song, C.Y., Tu, L.L., Karnieli, A. and Zhao, S.H. (2015) An Improved Mono-Window Algorithm for Land Surface Temperature Retrieval from Landsat 8 Thermal Infrared Sensor Data. Remote Sensing, 7, 4268-4289. https://doi.org/10.3390/rs70404268

[8] Jimenez-Munoz, J.C., Sobrino, J.A., Skokovic, D., Mattar, C. and Cristobal, J. (2014) Land Surface Temperature Retrieval Methods from Landsat- 8 Thermal Infrared Sensor Data. IEEE Geoscience and Remote Sensing Letters, 11, 1840-1843. https://doi.org/10.1109/LGRS.2014.2312032

[9] Yu, X.L., Guo, X.L. and Wu, Z.C. (2014) Land Surface Temperature Retrieval from Landsat 8 TIRS-Comparison between Radiative Transfers Equation Based Method, Split Window Algorithm and Single Channel Method. Remote Sensing, 6, 9829-9852. https://doi.org/10.3390/rs6109829

[10] Lin, S.P., Moore, N.J., Messina, J.P., DeVisser, M.H. and Wu, J.P. (2016) Evaluation of Estimating Daily Maximum and Minimum Air Temperature with MODIS Data in East Africa. International Journal of Applied Earth Observation and Geoinformation, 18, 128-140. https://doi.org/10.1016/j.jag.2012.01.004

[11] He, F., Liu, J.Y., Zhuang, D.F., Zhang, W. and Liu, M.L. (2007) Assessing the Effect 
of Land-Use/Landover Change on the Change of Urban Heat Island Intensity. Theoretical and Applied Climatology, 90, 217-226. https://doi.org/10.1007/s00704-006-0273-1

[12] Adinna, E.N., Enete, I.C. and Okolie, A.T. (2009) Assessment of UHI and Possible Adaptations in Enugu Urban Using Landsat-ETM. Journal of Geography and Regional Planning, 2, 030-036.

[13] Imhoff, M.L., Zhang, P., Woife, R.E. and Bounoua, L. (2010) Remote Sensing of Urban Heat Island Effect across Biomas in the Continental USA. Remote Sensing of Environment, 114, 504-513. https://doi.org/10.1016/j.rse.2009.10.008

[14] Weng, Q. (2008) Thermal Infrared Remote Sensing for Urban Climate and Environmental Studies: Methods, Applications, and Trends. ISPRS Journal of Photogrammetry and Remote Sensing, 64, 335-344. https://doi.org/10.1016/j.isprsjprs.2009.03.007

[15] Awuh, M.E. (2017) Assessment of the Impact of Land-Use/Land Cover Pattern on Urban Heat Island in Calabar Metropolis. Unpublished Ph.D. Thesis, Nnamdi Azikiwe University.

[16] Enete, I.C., Awuh, M.E. and Ikekpeazu, F.O. (2014) Assessment of Urban Heat Island (UHI) Situation in Douala Metropolis Cameroon. Journal of Geography and Earth Sciences, 2, 35-40.

[17] Abutaleb, K., Ngie, A., Darwish, A., Ahmed, M., Arafat, S. and Ahmed, F. (2015) Assessment of Urban Heat Island Using Remotely Sensed Imagery over Greater Cairo, Egypt. Advances in Remote Sensing, 4, 35-47. https://doi.org/10.4236/ars.2015.41004

[18] Allegrini, J., Dorer, V. and Carmeliet, J. (2015) Influence of Morphologies on the Microclimate in Urban Neighbourhoods. Journal of Wind Engineering and Industrial Aerodynamics, 144, 108-117. https://doi.org/10.1016/j.jweia.2015.03.024

[19] Keramitsoglou, I., Kiranoudis, C.T., et al. (2011) Identification \& Analysis of Urban Surface Temperature Patterns in Greater Athens, Greece, Using MODIS Imagery. Remote Sensing of Environment, 115, 3080-3090. https://doi.org/10.1016/j.rse.2011.06.014

[20] Inyang, P.E.B. (1980) Calabar Environs: Geographical Studies. University of Calabar, Calabar.

[21] National Population Commission (NPC) Nigeria (2006) Population Census of the Federal Republic of Nigeria. Analytical Report at the National Level, Lagos.

[22] Eni, D.D. and Ukpong, B.J. (2014) The Impact of Population Growth on Residential Land Use in Calabar, cross River State. Research on Humanities and Social Scisences, 4, 68-74.

[23] Zaharaddeen, I., Ibrahim, I.B. and Zachariah, A. (2016) Estimation of Land Surface Temperature of Kaduna Metropolis, Nigeria Using Landsat Images. Science World Journal, 11, 36-42.

[24] Nigeria Meteorological Organization (NIMET) (2010) Climate Variability and Change: Impact, Science, Innovation and Policy. Climate Review Bulletin, 1-24.

[25] Awuh, M.E., Officha, M.C., Okolie, A.O. and Enete, I.C. (2018) Land-Use/Land-Cover Dynamics in Calabar Metropolis Using a Combined Approach of Remote Sensing and GIS. Journal of Geographic Information System, 10, 398-414.

https://doi.org/10.4236/jgis.2018.104021 